\title{
INFLUENCE OF ONE WEEK EDUCATION PROGRAM ON THE KNOWLEDGE AND APPROACH OF PHARMACY STUDENTS TOWARDS DIABETES MELLITUS
}

\author{
Haji Muhammad Shoaib Khan ${ }^{1}$, Muhammad Asif ${ }^{1}$, Awais Qamar', Ayaz ul Hassan¹, Muhammad \\ Amir $^{1}$, Ghulam Murtaza ${ }^{2}$ \\ Abstracts: The objective of this study was to assess the improvement in knowledge and attitude of Pharmacy student towards \\ diabetes by implementing one week long education program. Study design: Study was conducted between April 25, 2011 to April \\ 29, 2011 which engaged the 3rd professional year Pharm. D. students comprising two groups: experimental and control groups. \\ Lectures and visual presentations on diabetic education and practice were conducted for five days. Three surveys were performed on \\ two groups i.e. non intervened control, non- intervened experimental and intervened experimental surveys. Questionnaire was used \\ as survey tool comprising of 46 questions under ten categories. Results: Scores in all diabetic knowledge aspect was increased after \\ education intervention and was significantly $(\mathrm{P}<0.05)$ different from that of control group. Conclusion: The marked increase in \\ knowledge about diabetes among pharmacy students illustrates the importance of educational intervention. Educational programs \\ may markedly increase the educational skills, efficiency and confidence of pharmacy students as well as professionals.
}

Key words: diabetes, educational intervention, visual simulations, questionnaire

\section{Influencia del Programa Una Semana de Educación en el Conocimiento y Enfoque de los Estudiantes de Farmacia hacia la Diabetes Mellitus}

Resumen: El objetivo del estudio fue evaluar cómo mejorar el conocimiento y la actitud de los estudiantes de Farmacia hacia la diabetes, mediante la implementación de un programa de educación de una semana. Diseño: El estudio se realizó entre el 25 y el 29 de abril de 2011, entre estudiantes de 3er año de la carrera de Farmacia, conformados en dos grupos: uno experimental y otro de control. Se llevaron a cabo conferencias y presentaciones visuales en educación y práctica de la diabetes durante cinco días. Tres estudios se realizaron en dos grupos: el grupo control y experimental no intervenido y el de estudio experimental intervenido. Un cuestionario se utilizó como herramienta de estudio con 46 preguntas en diez categorías. Resultados: Las puntuaciones en el conocimiento sobre todo aspecto de la diabetes se incrementó después de la intervención educativa, lo que fue significativo $(\mathrm{P}<0,05)$ diferente de la de grupo de control. Conclusión: El marcado aumento en el conocimiento sobre la diabetes entre los estudiantes de farmacia ilustra la importancia de la intervención educativa. Los programas educativos pueden aumentar notablemente la capacidad educativa, la eficiencia y la confianza tanto en los estudiantes de farmacia, así como en los profesionales.

Palabras clave: diabetes, intervención educativa, simulaciones visuales, cuestionarios

\section{Influência do Programa “Uma Semana de Educação no Conhecimento e Enfoque dos Estudantes de Farmácia para o Diabetes Mellitus"}

Resumo: O objetivo do estudo foi avaliar como melhorar o conhecimento e a atitude dos estudantes de Farmácia para o diabetes, mediante a implementação de um programa de educação de uma semana. Projeto: O estudo se realizou entre 25 e 29 de abril de 2011, entre estudantes de $3^{\circ}$ ano do curso de Farmácia, conformados em dois grupos: um experimental e outro de controle. Foram levadas a cabo conferências e apresentaçōes visuais em educação e prática do diabetes durante cinco dias. Três estudos foram realizados em dois grupos: o grupo controle e experimental sem intervenção e o grupo de estudo experimental com intervenção. Um questionário foi utilizado como ferramenta de estudo com 46 perguntas em dez categorias. Resultados: As pontuaçóes no conhecimento sobre todo aspecto do diabetes foi incrementado depois da intervençáo educativa, o que foi significativamente $(\mathrm{P}<0,05)$ diferente das do grupo de controle. Conclusão: O marcado aumento no conhecimento sobre o diabetes entre os estudantes de farmácia ilustra a importância da intervençáo educativa. Os programas educativos podem aumentar notavelmente a capacidade educativa, a eficiência e a confiança tanto nos estudantes de farmácia, bem como nos profissionais.

Palavras-chave: diabetes, intervenção educativa, simulaçóes visuais, questionários

\footnotetext{
${ }^{1}$ Faculty of Pharmacy and Alternative Medicine, The Islamia University of Bahawalpur, Bahawalpur 63100, Pakistan ${ }^{2}$ Department of Pharmaceutical Sciences, COMSATS Institute of Information Technology, Abbottabad 22060, Pakistan Correspondence: gmdogar356@gmail.com
} 


\section{Introduction}

Diabetes is a chronic disease marked by higher levels of blood glucose. It may prove to be slow killer if not properly managed. Around the world, about 17.1 million people were affected by diabetes in 2010 which are estimated to increase up to 36.6 million in 2030 (by $114 \%)\left({ }^{1}\right)$. Figures are more alarming in Pakistan, which is $6^{\text {th }}$ largest country with diabetic population of 4.9 million in 2010 which will increase up to 13.9 million in 2030 (by 267\%)(2). Moreover diabetes is $9^{\text {th }}$ leading cause of mortality around the globe (2) while $6^{\text {th }}$ in USA(3). To reduce these figures, World Diabetes Day is celebrated on November 14 by WHO, theme for which from 2009-2013 is "Diabetes Education and Prevention"(4). It emphasize on the diabetic education to know the risk factors of diabetes, how to respond to it, how to manage and control the diabetes.

American Diabetes Association in 1975 indicated that the medical health professional's attitude towards diabetic patient care was inappropriate which may lead to harmful effects on patient care (5). So there is need to educate and train the medical health professional to work as physician coordinated team, which also includes a pharmacist, to provide better health care to diabetic patients(6). Pharmacist being critical component of health care team must have integrated role in provision of effective medication to diabetic patients. To prove his role in reducing the global burden of diabetes and improving the patient's quality of life in the arena of health care, he must have complete knowledge and skills of the disease.

Pharmacist's knowledge and attitude is the key to achievement of better health outcomes. Nontraditional education at the undergraduate level to pharmacy students in collaboration with community health centers may be more effective in combating with the increasing figure of diabetic patients(7-9). Educating the students in educational institutions may be much fruitful in preventing the diabetes. Pharmacy collages may collaborate in community improvement projects involving pharmacy students to increase the recognition of diabetes in high risk urban popula- tions(10). Pharmacy students play a vital role in educating the adults who interact with the community pharmacies(11-13).

Educational integrated approach if adopted may help in provision of pharmaceutical care which will result in significantly reduced drug and dosage form related problems. Desired outcomes may be achieved by non-traditional education of health professionals regarding management of diabetes in combination with other complications and diseases e.g. hyperlipidemia, asthma and anticoagulant therapy(14). So, implementation of non-traditional diabetes educational programs is a great opportunity in developing the pharmacist which helps in improving the diabetic quality of life. Education assessment studies have been performed all around the world and in Pakistan as well.

In Pakistan where pharmacy infrastructure is under developmental stage, incorporation of nontraditional diabetes education programs will prove to be much beneficial in the advancement of pharmacy structure in Pakistan and lead to the establishment of physician supporting work team for effective patient care. Based on these facts, present study was conducted.

\section{Experimental}

\section{Study design}

The educational program which was conducted between April 25, 2011 to April 29, 2011 encompassing five days lectures with incorporation of visual simulations for self-management, diagnostic tools and management of diabetes. Pharmacy students from $3^{\text {rd }}$ professional year comprising a total of 325 students participated this one week educational program. The students were randomly divided into two groups: experimental and control groups. Institutional permission was obtained before implementing the Diabetes Knowledge Assessment Program. 
For educational intervention, 5 hours of credit were conducted. Each session comprised of three portions i.e. i) Instructive lecture, ii) visual simulations and iii) questioning session. Visual simu- lations comprised videos related to diabetes aspects. Specific learning objectives about diabetes are highlighted in Table 1.

\begin{tabular}{|c|c|c|c|}
\hline Time-frame & Instructive lecture & Components & Visual simulations \\
\hline Day 1 & $\begin{array}{l}\text { An introduction to Dia- } \\
\text { betes mellitus }\end{array}$ & $\begin{array}{l}\text { - Introduction } \\
\text { - Time-line history } \\
\text { - Types } \\
\text { - Patho-physiology } \\
\text { - Risk factors } \\
\text { - Complication } \\
\text { - Diagnosis }\end{array}$ & $\begin{array}{l}\text { - Mechanism of type-I, type-II and gesta- } \\
\text { tional diabetes mellitus } \\
\text {-Arousal of complications due to hyper- } \\
\text { glycemia }\end{array}$ \\
\hline Day 2 & Glucose monitoring & $\begin{array}{l}\text { - Glucose tests } \\
\text { - Self-glucose monitoring } \\
\text { - Types of glucometer } \\
\text { - Daily glucose monitoring } \\
\text { pattern }\end{array}$ & - Use of glucometer \\
\hline Day 3 & Anti-diabetic therapy & $\begin{array}{ll}\text { - } & \text { Insulin administration } \\
\text { - } & \text { Insulin auto-injectors } \\
\text { - } & \text { Complications during insu- } \\
& \text { lin therapy } \\
\text { - } & \text { Non-insulin therapy }\end{array}$ & Self-use insulin auto-injectors \\
\hline Day 4 & $\begin{array}{l}\text { Nutrition and physical } \\
\text { activities }\end{array}$ & $\begin{array}{l}\text { - Importance of dietary pat- } \\
\text { terns } \\
\text { - Physical activities as non- } \\
\text { medication therapy }\end{array}$ & $\begin{array}{l}\text { - Glucose monitoring during physical } \\
\text { activities }\end{array}$ \\
\hline Day 5 & $\begin{array}{l}\text { Diabetes plus other } \\
\text { chronic diseases } \\
\text { Foot-care program }\end{array}$ & $\begin{array}{l}\text { - therapeutic precaution dur- } \\
\text { ing cardiac diseases, asthma } \\
\text { - diabetic foot care } \\
\text { - foot care treatment }\end{array}$ & - living with diabetic foot-care \\
\hline
\end{tabular}

Table 1. Specific learning objectives about diabetes

\begin{tabular}{|l|l|l|l|}
\hline & Pre-intervention (\%) & Post-intervention (\%) & p-value \\
\hline General Knowledge of Diabetes & 72.33 & 87.754 & 0.0178 \\
\hline Risk Factors & 60 & 90.20 & 0.0040 \\
\hline Symptoms & 79.93 & 95.57 & 0.0062 \\
\hline Complications & 70.61 & 88.57 & 0.01157 \\
\hline Medications Available & 79.59 & 90.81 & 0.0288 \\
\hline Life Style and Non-Medical Measures & 71.76 & 92.17 & 0.0063 \\
\hline Preventions & 67.75 & 86.53 & 0.0022 \\
\hline Diet & 51.53 & 72.44 & 0.0206 \\
\hline Monitoring of Diabetes Conditions & 83.16 & 95.91 & 0.0213 \\
\hline
\end{tabular}

Table 2. Pre-intervention versus pro-intervention analysis 
All students were engaged to participate the lectures, visual simulations and were encouraged in questioning session.

\section{Questionnaire development}

Questionnaire was used as survey instrument. Diabetic Knowledge Assessment Test was produced comprising 46 questions under 10 categories indicated in Table 2. Diabetic Knowledge Assessment Test is available by mail from corresponding author.

\section{Data assessment}

The score for each question was calculated by counting the total number of correct answers in a batch relative to that question. For each category, mean was calculated by statistical analysis. Individual data as well as cumulative data of a single category using ANOVA was subjected to statistical analysis to obtain the significance of difference between the batches. The level of significance was set at 0.05 .

Category data was evaluated in two different ways. i) Pre- and Post-intervention comparative analysis, ii) control and experimental comparative analysis.

\section{Results}

Out of total 650 students participating this Diabetes Knowledge Assessment Program, 325 students received educational intervention. Complete data for 3 surveys was included for analysis i.e. pre-intervention data, post-intervention data and control data. Data results are compiled in category form in two ways. Comparing pre-intervention survey with post-intervention, diabetic knowledge among the students receiving educational intervention, increased significantly $(\mathrm{P}<0.05)$. The mean percentage score for all the questions was increased from $70.67 \%$ to $89.08 \%$. General knowledge of students about diabetes was increased by an average of $15.41 \%$. Similarly significant $(\mathrm{P}<0.05)$ increase was observed for knowledge about risk factors, life style and dietary habits by $30.20 \%, 20.41 \%$ and $20.92 \%$ respectively. $10-20 \%$ increase in knowledge was observed for symptoms, complications, medication, prevention and diabetes monitoring.

In second part of analysis, experimental results are compared with control batch which also show a significant $(\mathrm{P}<0.05)$ difference of knowledge about diabetes between two groups. Results are somewhat similar to that of pre- vs. post intervention analysis. More than 20\% difference was observed for knowledge about dietary pattern for diabetic patient. General knowledge, knowledge about risk factors and precaution was more than $15 \%$. Other categories had also a significant $(\mathrm{P}<0.05)$ difference more than $10 \%$ which represents the impact of educational intervention on experimental batch.

\section{Discussion}

Educating the undergraduate pharmacy students is the leading step towards developing the most skilled and competent pharmacists and incorporating them into the community health setup to prevent the diabetes and bring about excellence in its management. It may be supportive in decreasing the augmenting figures of diabetic population.

The main goal of this Diabetes Knowledge Assessment Program was to increase the scores of pharmacists toward knowledge of diabetes. The results show that non-intervened pharmacy students have good knowledge about diabetes than those without educational intervention. Results are quite satisfactory as far as the knowledge about medication and monitoring is concerned. But the general knowledge about diabetes, its risk factors, complications and dietary patterns is quite unsatisfactory among the non-intervened student probably because of their less exposure to general information about diabetes in traditional curriculum. Rather they are best at their knowledge in medication. The individuals have suggested also number of related therapies in the survey under the "other medication and treatments you know". Maximum increase was observed for the knowledge about the risk factors leading to diabetes and life style changes and non-medication therapy to 
prevent the diabetes. This is due the fact that visual simulations have been incorporated beside the instructive lectures, which has imposed a lasting image over the minds of student. This indicates that visual and practical simulation about the diabetes may be more productive in training the students.

There were also some limitations during implementing the survey. Selection of individuals was not randomized which would otherwise produce more operative results. The compliance of the individuals towards educational program was enhanced by incorporating the visual simulations.

\section{Conclusion}

The program has revealed that the non-traditional education among the pharmacy students is an effective tool of increasing their knowledge and skills. Institutions may help in reinforcement of implementing such educational programs which may also help in standardizing the educational procedures. Diabetic education intervened students in a position to play an effective role in physician assisting health care team as well as in community health care centers for effective and better patient care.

\section{References}

1. 10 leading causes of death in U.S., 2004. Available at http://www.infoplease.com/ipa/A0005110.html. Accessed June 30, 2011.

2. Sarah W, Richard S, Gojka R, et al. Global prevalence of diabetes mellitus. Diabetes Care 2004; 27: 10471053.

3. World Health Organization. The top 10 causes of death. Available at http://who.int/mediacentre/factsheets/ fs310/en/ Accessed June 30, 2011.

4. International Diabetes Federation. Diabetes education and prevention. Available at http://www.idf.org/ worlddiabetesday/2009-2013 Accessed June 2011.

5. Department of Health. Report of National Commission on Diabetes to Congress of United States. Vol. 3, Part 5 Washington, DC: US Government Printing Office; 1975. Education and Welfare. HIH publication 76-1024; $5-13$.

6. American Diabetes Association. Standards of medical care in diabetes-2009. Diabetes Care 2009; 32 (Supp 1): $S 13-S 49$.

7. Johnson JF, Chesnut RJ, Tice BP. An advanced diabetes care course as component of a diabetes concentration. AM J Pharm Edu 2003; 67(1) Article 21.

8. Odegard PS, LaVigne LL, Ellsworth A. A diabetes education program for pharmacy students. Am J Pharm Educ 2002; 66(4): 391-395.

9. Ryan GJ, Foster KT, Unterwagner W, Jia H. Impact of a diabetes certificate program on PharmD students' knowledge and skills. Am J Pharm Educ 2007; 71(5) Article 88.

10. Johnson JF. Involvement of a pharmacy college in a community diabetes improvement project. International Pharmaceutical Abstracts American Association of Colleges of Pharmacy Annual Meeting 2001; 102(Jul): 20. 
Knowledge and Approach of Pharmacy Students towards Diabetes mellitus - Haji Shoaib Khan et al.

11. Letassy, N Dennis, V Lyons, et al. Know your diabetes risk project: Student pharmacists educating adults about diabetes risk in a community pharmacy setting. International Pharmaceutical Abstracts Journal of the American Pharmaceutical Association 2010; 50(2): 188.

12. Shane-McWhorter, L Oderda. Providing diabetes education and care to underserved patients in a collaborative practice at a Utah community health center. International Pharmaceutical Abstracts Pharmacotherapy 2005; 25(1): 96-109.

13. Williamson AF. Williamson JA. Meeting the challenge: interdisciplinary diabetes education program conducted in a community pharmacy setting. International Pharmaceutical Abstracts APhA Annual Meeting 1995; 142(Mar): 98.

14. Norton JLW, Gibson DL. Establishing an outpatient anticoagulation clinic in a community hospital. Am J Health Syst Pharm 1996; 53: 1151-1157.

Received: October 17, 2011

Accepted: November 22, 2011 